\title{
LIBERALNA PRAVA IZMEĐU RADIKALNE DEMOKRATSKE KRITIKE I NEUSPEHA
}

\section{LIBERALIZMA}

\author{
Nenad Dimitrijević \\ Central European University
}

\begin{abstract}
SAŽETAK
Ovaj rad polazi od stava da je nepoštovanje individualnih prava osnovni problem današnje liberalne demokratije. U njemu autor zauzima stav da demokratija nije vredna sama po sebi. Ustavna demokratija je legitiman politički režim samo ako je u stanju da afirmiše i zaštiti individualnu autonomiju svakog državljanina. Fokus teksta je na radikalno-demokratskoj kritici liberalnih prava, ali je ograničen na nekoliko važnih tačaka neslaganja između liberalno-demokratskog i radikalno-demokratskog razumevanja osnovnih prava. Analiza je fokusirana na one elemente liberalnog razumevanja prava koje radikalno-demokratska kritika vidi kao sporne. Drugi odeljak sumira pojam radikalne demokratije i nudi jednu moguću klasifikaciju različitih radikalno-demokratskih pristupa osnovnim pravima. Razlikuju se dva radikalno-demokratska pristupa: prvi odbacuje prava, dok drugi poziva na njihovo alternativno promišljanje. Treći odeljak prihvata radikalno-demokratski stav o potrebi redefinisanja standardne liberalne teze o relativnoj nezavisnosti lične, društvene i političke sfere. Normativni stav koji autor zastupa glasi da je kriza posledica dugotrajnog procesa u kome su liberalne demokratije postepeno napustile sopstvene vrednosne osnove. Na kraju, autor zaključuje da razmišljanje o mogućim putevima obnove pravnog i moralnog autoriteta liberalnih prava zahteva da preispitamo pojam liberalne jednakosti i da se zapitamo o održivosti konvencionalne liberalne institucionalne arhitekture.
\end{abstract}

KLJUČNE REČI: Liberalna prava, radikalno demokratska kritika, liberalizam, ustavna demokratija

\section{Kontakt autora:}

Nenad Dimitrijević, Central European University, Political Science Department, Nádor u. 9, 1051 Budapest, Hungary.

E-pošta:dimitrij@ceu.edu. 
POLITIČKE PERSPEKTIVE

ČLANCI I STUDIJE

\section{UvOD}

Ovaj rad polazi od stava da je nepoštovanje individualnih prava osnovni problem današnje liberalne demokratije. Tvrdiću da demokratija nije vredna sama po sebi. Ustavna demokratija je legitiman politički režim samo ako je u stanju da afirmiše i zaštiti individualnu autonomiju svakog državljanina. U političkoj zajednici, individualna autonomija se prevodi u princip jednake slobode za sve, koji se potom formalizuje u katalogu osnovnih ustavnih prava. Mnogi liberali se neće složiti sa tezom o instrumentalnom kvalitetu demokratije, ali porodične razmirice ovom prilikom ostavljam po strani. Fokus mog teksta je na radikalno-demokratskoj kritici liberalnih prava. Ta kritika je deo šireg projekta koji tvrdi da liberalna demokratija počiva na pogrešno shvaćenom odnosu između individualne autonomije, prirode društvenih odnosa i političkog zajedništva. U sledećem koraku, radikalna demokratija insistira na neophodnosti teorijskog i praktičnog redefinisanja ovih kategorija i njihovog odnosa.

Tekst ne nudi sveobuhvatan pregled radikalno-demokratskih teorija. Ograničiću se na nekoliko važnih tačaka neslaganja između liberalno-demokratskog i radikalno-demokratskog razumevanja osnovnih prava. Analiza je fokusirana na one elemente liberalnog razumevanja prava koje -radikalno-demokratska kritika vidi kao sporne.

Ovom uvodu slede dva odeljka. Drugi odeljak sumira pojam radikalne demokratije i nudi jednu moguću klasifikaciju različitih radikalno-demokratskih pristupa osnovnim pravima. Razlikovaću dva radikalno-demokratska pristupa: prvi odbacuje prava, dok drugi poziva na njihovo alternativno promišljanje. Treći odeljak prihvata radikalno-demokratski stav o potrebi redefinisanja standardne liberalne teze o relativnoj nezavisnosti lične, društvene i političke sfere. Ovaj stav se danas može braniti upućivanjem na jednostavne empirijske uvide: aktuelna kriza je u velikoj meri obesmislila liberalnu tezu o razlikovanju privatnog i javnog. Normativni stav koji ću zastupati glasi da je kriza posledica dugotrajnog procesa u kome su liberalne demokratije postepeno napustile sopstvene vrednosne osnove. Tvrdiću da razmišljanje o mogućim putevima obnove pravnog i moralnog autoriteta liberalnih prava zahteva da preispitamo pojam liberalne jednakosti i da se zapitamo o održivosti konvencionalne liberalne institucionalne arhitekture. 
NENAD DIMITRIJEVIĆ

LIBERALNA PRAVA IZMEĐU RADIKALNE

DEMOKRATSKE KRITIKE I NEUSPEHA LIBERALIZMA

\section{Pogled SA LeVE STRANE: ŠTA NIJE U REDU SA LIBERALNIM PRAVIMA?}

\subsection{RADIKALNA DEMOKRATIJA: JEDNA SKICA}

Zastupnici radikalne demokratije nisu saglasni oko značenja ovog pojma. Pogledajmo na primer agonizam, koji uživa autoritet jedne od najuticajnijih teorija radikalne demokratije. Agonizam ne prihvata odbacivanje vrednosnih i institucionalnih načela liberalne demokratije:

Ako se složimo da se savremena demokratija zasniva na principu slobode i jednakosti svih ljudi, jasno je da nije moguće urediti društvo na osnovu radikalnijih principa. Problem nisu ideali moderne demokratije, već činjenica da se njeni politički principi ne primenjuju. (Mouffe 1992, 1)

Šantal Mufe (Chantal Mouffe) nam ovde kaže da radikalna misao ne bi trebalo da osporava liberalne principe. Nema razloga da ne priznamo primat slobode i jednakosti i institucionalni okvir zasnovan na vladavini prava i podeli vlasti. Umesto ideološkog odbacivanja liberalizma, važno je „produbiti demokratsku revoluciju koja je pokrenuta pre dvesta godina“, odnosno „radikalizovati savremenu demokratsku tradiciju” (Ibid). Ovakav pristup pretpostavlja napuštanje marksističke teorije, političkog projekta državnog socijalizma, ${ }^{1}$ kao i osporavanje liberalnog shvatanja racionalnosti i težnje ka konsenzusu. Radikalna demokratija treba da se koncentriše na rekonceptualizaciju pojmova pluralizma, konflikta i identiteta. Ispravno razumevanje odnosa ova tri pojma proizvelo bi novo shvatanje političkog. Umesto liberalnog pristupa koji zahteva stabilizaciju postojećih društvenih odnosa putem formalne politike i prava, radikalna demokratija zahteva njihovu transformaciju. Taj cilj može se ostvariti samo ako se agonistički pluralizam afirmiše kao fokus političke prakse (McNeilly 2016, 275).

Za razliku od agonizma, većina teorija o radikalnoj demokratiji insistira na potpunom odbacivanju liberalizma. Osnovna tvrdnja glasi da liberalni institucionalni okvir onemogućava istinsko političko samoupravljanje i da zato treba biti napušten. Istovremeno, kritičari se slažu sa agonizmom da liberalizam ograničava domet pluralizma formalizovanjem apstraktnih racionalnih identiteta i insistiranjem na razlici između društvenog i političkog. Takav pristup smanjuje prostor za legitiman konflikt, svodeći politiku na pravno uobličenu debatu između pravno priznatih aktera, koji su unapred ograničeni ustavnim tumačenjem konsenzusa. Ovo je pogrešno, veli kritika: demokratska politika se ne može svesti na proceduralno korektno donošenje obavezujućih odluka koje bi se zasni-

1 „Iako je neophodno napustiti ideju o socijalizmu kao alternativnom sistemu čije uspostavljanje zahteva odbacivanje liberalno-demokratskih političkih principa, to ne znači da se trebamo odreći socijalizma kao vida borbe za produbljivanje demokratije." (Mouffe 1993, 9o) 
vale na pretpostavci postojanja osnovnog konsenzusa. ${ }^{2}$ Pozitivan argument glasi da demokratski proces mora dopustiti slobodno izražavanje istinskog pluralizma i istinskih sukoba. Ovaj pluralizam trebao bi biti slobodan od predefinisanih liberalnih identiteta (npr. 'Ja, nosilac prava', 'Mi, narod'), a njegov domet ne bi bio ograničen obavezujućim pravnim konstruktima koji štite navodno zajedničke vrednosti (npr. Rolsovi 'ustavni osnovi'). Politika se treba misliti kao borba za moć između stvarnih društvenih aktera. Razlike u interesima, pogledima na svet i društvenom položaju zahtevaju da sukobi i neslaganja budu pretočeni u konstitutivne elemente demokratije (Ingram 2006, 38). O legitimitetu demokratije sudi se na osnovu otvorenosti procesa u kome bi svako imao pravo da učestvuje i da se suprotstavi svakome. Jedino - konceptualno i analitički nedovoljno jasno - ograničenje sastojalo bi se u obavezi poštovanja drugih kao ravnopravnih učesnika u političkom. Takva autentična demokratska participacija prevazišla bi kapitalističko ugnjetavanje i omogućila bi društvenu i političku pravdu tako što bi poništila prikrivene liberalne hijerarhije skrivene iza maske političke neutralnosti (setimo se pola, klase, etničke pripadnosti ili rase).

Šta se u ovom scenariju dešava sa liberalnim pravima? Teorije radikalne demokratije tvrde da je demokratija važnija od ljudskih prava. Međutim, ove teorije čine širu porodicu u kojoj prepirke oko pitanja individualnih prava nisu retke. Ovaj tekst razlikuje dve vrste radikalno-demokratskih pristupa pravima: prvi odbacuje prava, a drugi poziva na njihovu rekonceptualizaciju na osnovu jednog drugačijeg tumačenja demokratije.

\subsection{RADIKALNO-DEMOKRATSKO ODBACIVANJE INDIVIDUALNIH PRAVA}

Sredinom sedamdesetih godina prošlog veka škola Kritičkih pravnih studija (KPS) oživela je staru marksističku tezu o pravu kao političkom izrazu dominantnih društvenih interesa. Pravne norme i sudske odluke tek su „stilizovana verzija političkog diskursa” (Sciaraffa 1999, 201) koji je zasnovan na klasnim podelama. Na osnovu ove teze, KSP izvode radikalne zaključke o pravima, koje pravni teoretičar Dankan Kenedi (Duncan Kennedy) sažima kao Marksom inspirisan „gubitak vere u prava” (Kennedy, $\mathrm{Du}$ 2002, 183). Teoretičar međunarodnog prava Dejvid Kenedi (David Kennedy) iznosi sličan argument kad tvrdi da su ljudska prava preuska i preslaba kako bi ispunila zahteve ljudske emancipacije. Prava se koncentrišu na odnos pojedinaca i vlasti, zanemarujući ključne kolektivne - 
NENAD DIMITRIJEVIĆ

LIBERALNA PRAVA IZMEĐU RADIKALNE

DEMOKRATSKE KRITIKE I NEUSPEHA LIBERALIZMA

ekonomske, društvene, kulturne - strukture i procese koji osporavaju slobodu (Kennedy, Da 2012, 24).

Prema ovom tumačenju, apstraktni liberalni individualizam previđa da su stvarna ljudska bića integrisana u društvo. Ovaj izvod brzo prerasta u metodološki kolektivizam. Kolektivizam, utemeljen u stavu da se društvo temelji na supstantivnom dobru višeg reda, osporava ključne liberalne teze o primatu lične autonomije i o pravima kao instrumentima zaštite te autonomije. Osporavanje je potkrepljeno jednom vrstom empirijskog uvida: sveprisutna ustavna i ljudska prava nisu iskorenila arbitrarnost vlasti, eksploataciju, represiju i nasilje. Krivicu treba tražiti u liberalizmu, pa tako i u liberalnim pravima. Sâmo postojanje prava u duboko nepravednom svetu svedoči o njihovoj beskorisnosti.

KSP ide i dalje. Liberalna prava nisu naprosto beskorisna: ona su takođe i štetna, jer ,zagovaraju politiku nadmetanja među podvlašćenima, propagirajući ideje o viktimizaciji i ovlašćenjima, istovremeno otežavajući nastanak savezništava i pronalaženje rešenja koja bi bila zasnovana na kompromisu i zajedništvu" (Ibid). Ukratko, liberalna prava su instrumenti koji pravno formalizuju ljudsku slabost i ranjivost. Ovoj važnoj tezi vratiću se u narednom odeljku. Ovde vredi pomenuti da do istog zaključka dolaze i neke druge postmarksističke radikalne kritike prava. Na primer, Alan Bodiu (Alain Badiou) $(2013,107)$ tvrdi da ljudska prava formalizuju identitete na način koji stvarne ljude pretvara u žrtve. ${ }^{3} \mathrm{U}$ jednoj često citiranoj izjavi, on veli:

Floskula „ljudska prava” tek je ideologija savremenog liberalnog kapita-

lizma: nećemo vas pobiti, nećemo vas mučiti u pećinama, zato ne dižite glas i klanjajte se zlatnom teletu (Cox, Whalen, Badiou 20o1).

Za Bodiua, ljudska prava predstavljaju jednu od odlika vladajuće liberalne etičke ideologije koja određuje dobro kao zaštitu od zla. „Ljudska prava su... prava da ne budete vređani ili zlostavljani na način koji može ugroziti vaš život (strahote ubistva i pogubljenja), vaše telo (strahote mučenja, okrutnosti i gladi) ili vaš kulturni identitet (strahote ponižavanja žena, manjina, itd.)." (Badiou 2013, 9) Ove strahote, međutim, predstavljaju proizvod upravo one civilizacije koja naglašava zaštitu ljudskih prava, pa je u tom smislu ideologija ljudskih prava jednostavno cinična. Drugo, etički konsenzus o pravima zasnovan na ideji zaštite od zla u suštini je konzervativan, jer sprečava afirmaciju pozitivne ideje dobra. ${ }^{4}$

3 „Kada čujem kako ljudi kažu 'Nas ugnjetavaju zato što smo crnci, žene', imam samo jedno pitanje: šta tačno znači biti 'crnac' ili 'žena'? Ako se ovaj ili onaj identitet koristi u borbi protiv ugnjetavanja, onda identitet sam po sebi počinje da deluje progresivno, a ne kao svojstvo koje je ugnjetavanom pripisao onaj koji ugnjetava." (Badiou 2013, 107)

$4 \quad$,... Ono što etika opravdava zapravo predstavlja pokušaj takozvanog 'Zapada' da očuva ono što poseduje." (Ibid, 14) 
Pogledajmo detaljnije ove dve teze. Liberali bi možda mogli reći da je teza o 'zaštiti od zla', jednom kad se oslobodi od teškog ideološkog vokabulara, srodna njihovim stavovima: prava su instrumenti kojima se lična autonomija štiti od različitih opasnosti. Oni se verovatno ne bi suprotstavili ni tvrdnji da liberalni režimi zapravo sâmi proizvode dobar deo zla od kog se treba štititi. Međutim, ovo zapažanje samo naglašava važnost osnovne ideje klasičnog liberalizma: svaka državna vlast je prima facie loša, pa su nam prava upravo zato neophodna. Odbacujući ovaj argument, Bodiu uvodi drugu tezu: prava su izvor nepravde. Liberalna prava konzerviraju stanje represije sprečavajući nas da se okrenemo alternativi. Alternativa, koja zahteva revoluciju, sastoji se u afirmaciji Dobrog koje ne bi funkcionisalo kao zaštita od zla, i koje ne bi bilo ograničeno pravnim i političkim okovima. Pravo i politika neprijatelji su istinske slobode (Badiou 2012, 59).

KSP i Bodiu odbacuju liberalnu ideju o pravnom sistemu kao neophodnom okviru ljudske slobode. Kritika liberalne 'juridifikacije' društvenih i političkih odnosa jedna je od središnjih tema radikalne demokratije. Ugo Matei (Ugo Mattei), profesor prava i vodeći teoretičar italijanskog društvenog pokreta Zajednička dobra (Beni Comuni), najdosledniji je u iznošenju ove kritike. Očigledno inspirisan Lenjinom (Lenin 1962; 1977), Matei razlikuje principijelan i strateški odnos prema pravu. Kršenje zakona je principijelno ako se na taj način izaziva režim i ukazuje široj javnosti zašto pokret smatra da je režim nelegitiman. S druge strane, pokret se „prema državnim institucijama često ophodi strateški, nedosledno i oportunistički”. (Bailey \& Mattei 2013, 970)5 Matei vidi takvo delovanje kao „primenu nacionalnog ustava... kroz kontrahegemonijsku upotrebu prava”. (Ibid, 1012) Odbacivanje autoriteta države i prava praćeno je iskazivanjem odanosti osnovnim vrednosnim načelima ustava osporavanog režima. To je jedino ispravno postupanje jer Marksov stari zaključak i dalje stoji: liberalna prava nisu ništa drugo do ustavno-pravna iluzija koja prikriva istinske odnose moći. Radikalan zaključak glasi da pojam lične autonomije i individualna ustavna prava treba odbaciti: „Zajednička dobra suštinski se ne uklapaju u ideju o ličnoj autonomiji koju je razvila na pravima zasnovana kapitalistička tradicija”. (Mattei, 2011) ${ }^{6}$

Kritika koja insistira na uvidu u nepovratni slom društvene pravde i političkog legitimiteta, u sledećem koraku treba da definiše alternativu.

6 Slični zaključci iznose se u izdanju koje proučava pouke pokreta Okupiraj (Occupy): „Ideje o ličnoj slobodi, kreativnosti, ličnom ostvarenju i uravnoteženosti između posla i privatnog života trenutno služe kapitalu, dok ideje o neorganizovanosti i nedostatku jasnih ciljeva mogu predstavljati istinski otpor". (Colebrook 2015, 129) 
Alternativa nam kazuje kako ispravno razumeti društvene odnose, politiku, pravo i demokratiju:

[...] Zajednica pojedinaca ili društvenih grupa povezana je uzajamnim horizontalnim vezama u mrežu u kojoj je moć raspršena; hijerarhija (i konkurencija proizvedena po istoj logici) odbacuju se zarad društvenog modela koji se zasniva na učešću i saradnji, koji sprečava koncentraciju moći u rukama jedne stranke ili aktera, te stavlja interes zajednice u centar. (Mattei, 2011)

Bît alternative sastoji se u kreiranju sistema sveobuhvatne solidarnosti. Solidarnost je kolektivni i horizontalni proces zajedničkog života koji afirmiše istinsku slobodu, jednakost, društvenu pravdu, međusobno poštovanje i uzajamnu brigu povezanih aktera. Taj proces se ne može formalizovati u pravni i politički poredak. 'Mi-perspektiva' treba da uživa primat, ali ovaj novi kolektivizam ne bi ugrozio autentične individualne identitete. Mi koje liberalni kapitalizam ugnjetava i prisilno individualizuje („mi potčinjeni, medijatizovani, prezaduženi i politički predstavljeni” (Hart i Negri 2012) prvenstveno moramo prihvatiti nužnost pobune protiv stanja u kom se nalazimo. Zatim moramo shvatiti da pobuna i bolja alternativa postaju moguće tek nakon što naučimo da komuniciramo na nov način, kao ravnopravne osobe udružene u alternativnom 'jedinstvu' (singularity). U tome leži suštinsko značenje čuvenog pojma 'mnoštvo' (multitude): istinska sloboda i jednakost svake osobe funkcionišu samo pod uslovom postojanja istinskog zajedništva.

\subsection{RADIKALNO-DEMOKRATSKO ZALAGANJE ZA INDIVIDUALNA PRAVA}

Važno je zapitati se da li nam radikalno-demokratska kritika liberalnih prava može reći nešto o razlozima zbog kojih liberalna prava gube na značaju. Pozabaviću se ovim pitanjem analizirajući tačke naslaganja između liberalizma i onih radikalno-demokratskih teorija koje prihvataju vrednost ljudskih prava.

Neslaganja su mnogobrojna. Osnovna tačka razlaza tiče se vrednosne osnove individualnih prava. Moderni konstitucionalizam počiva na pojmovnom, vrednosnom i institucionalnom primatu lične autonomije. Ustavom garantovana autonomija pruža svakom građaninu jednaku šansu da vodi dobar život, tako što stvara prostor za razumne odluke u oblasti definisanoj ličnim pravima i vladavinom prava. Istovremeno, autonomija je i obaveza da se poštuje jednako pravo svih drugih ljudi da upravljaju sopstvenim životima. Prava određuju prostor razumnih ličnih odluka. Ovaj prostor je zaštićen institucionalnim aranžmanima zasnovanim na vladavini prava i ograničenju vlasti. Prava štite pojedince od delovanja vlasti, bez obzira šta vlast o tome misli: da je u određenoj situaciji ograničenje odre- 
POLITIČKE PERSPEKTIVE

ČLANCI I STUDIJE

đenih prava neophodno, da bi većini ljudi bilo bolje ako bi se neka prava suspendovala, ili da bi se stanje pravde, društvene dobrobiti, bezbednosti ili političke stabilnosti poboljšalo ako bi prava bila ograničena (Sajo and Uitz 2017, 372).

Liberalna prava su univerzalna, što znači da su zagarantovana svim članovima jedne političke zajednice (kao ustavna prava), te svim pripadnicima ljudskog roda (kao ljudska prava definisana u međunarodnom javnom pravu). Mi smo jednaki pred zakonom, odnosno svi imamo ista prava. Ali ko smo mi? Ko su osobe koje smatramo nosiocima prava? Logika je jasna: mi se kao ljudska bića razlikujemo po mnogo čemu. Zbog toga je neophodna jednakost koja neće voditi ka nametnutoj uniformnosti: neophodno je pronaći nivo jednakosti koji bi nekako svima garantovao autonomiju i ličnu posebnost. Prava su zato apstraktna. Univerzalni karakter prava podrazumeva zanemarivanje naših jedinstvenih individualnih identiteta. Prava pružaju opšti okvir unutar kog svaki pojedinac može slobodno da sledi svoje interese i da razvija svoj identitet. Prava nas određuju kao apstraktne građane, a ne kao stvarna ljudska bića.

Takav pristup se ne dopada radikalnim demokratama. Oni smatraju da su liberalno tumačenje lične autonomije i prateće poimanje osnovnih prava apstraktni, atomistički, indiferentni prema društvenom kontekstu, slepi prema stvarnim ljudskim identitetima i zasnovani na pogrešnom shvatanju moći. Različite kritičke teorije, poput ortodoksnog marksizma lenjinizma, metafizičkog revolucionarnog komunizma, feminizma, komunitarizma, agonizma, kulturnih studija i raznolikih postmodernističkih pristupa, slažu se u stavu da liberalizam grubo uprošćava i pogrešno predstavlja pitanja vezana za odnos lične autonomije i zajedništva. Jednostavno rečeno: liberalizam na pogrešan način tumači ljudsko stanje, što dovodi do iskrivljenog poimanja svih bitnih ideja, od individualne slobode, preko jednakosti, sve do karaktera političke zajednice. Ova kritika kao da se ne udaljava od postulata koje je postavio mladi Karl Marks (Karl Marx). Marks analizira način na koji američki i francuski ustavi pristupaju pravima i zaključuje:

Sloboda je, dakle, pravo činiti sve što drugome ne škodi. Granica u kojoj se svatko može kretati bez štete po drugoga određena je zakonom, kao što je granica dvaju polja određena međašem. Radi se o slobodi čovjeka kao izolirane, u sebe povučene monade... Čovjekovo pravo na slobodu prestaje biti pravo, čim dođe u sukob s političkim životom, dok je, prema teoriji, politički život samo garancija čovjekovih prava, prava individualna čovjeka, te, dakle, mora biti napušten čim protivrječi svome cilju, ovim čovjekovim pravima. (Marx 1989, 68, 71)

Marks zavređuje priznanje. Pre svega, bez obzira na njegova vrednosna uverenja, on nudi dobar analitički prikaz koncepta političke neutralnosti liberalne države. Drugo, on neće naprosto odbaciti liberalni projekat kao 
NENAD DIMITRIJEVIĆ

LIBERALNA PRAVA IZMEĐU RADIKALNE

DEMOKRATSKE KRITIKE I NEUSPEHA LIBERALIZMA

formalistički: politička emancipacija uobličena osnovnim pravima ima svoju vrednost, ali samo ako se shvati kao nedovršeni projekat, odnosno istorijski iskorak u smeru potpune ljudske emancipacije. Marksove poteškoće počinju sa njegovim tumačenjem odnosa između društvene i političke sfere. On će tvrditi da univerzalistička aspiracija ustavnih prava pada u sudaru sa kapitalističkim kontekstom. Taj sudar obelodanjuje činjenicu da su 'prava čoveka i građanina' u stvari društveno uslovljeni partikularni konstrukti, odnosno ništa drugo do 'legalističke maske' koje prikrivaju stvarnost. Istinski univerzalizam postaće moguć tek nakon što se prevaziđe ekonomski osnov građanskog egoizma i političkog zajedništva (Ibid).

Marksovi sledbenici naglašavaju negativne aspekte njegove kritike:

Uopštavajuće razumevanje pravnog sistema, karakteristično za liberalnu pravnu teoriju, polazi od binarnih podela [um/telo, razum/emocije, priroda/kultura - N.D.] i svodi pojedinca na apstraktnu, hiperracionalnu, samovoljnu jedinku izuzetu iz društvenog konteksta, sistematski je lišavajući njenih posebnosti, njene kompleksnosti i njene materijalnosti. (Grear 2007, 522)

Uspostavljajući apstraktni okvir negativne autonomije, prava promovišu identitete nepostojećih osoba. Oni koji ne postoje nemaju nikakav značaj, pa je i njihova zaštita nevažna. Sledi da je greška liberalizma analitičke prirode. Liberalizam barata apstraktnom ljudskom egzistencijom, identifikuje probleme koje ta egzistencija navodno proizvodi, a zatim konstruiše rešenje u vidu individualnih prava „shvaćenih kao vlasništvo svakog sadašnjeg i budućeg ljudskog bića." (McNeilly 2016, 271) Međutim, istina je sasvim drugačija. Liberalna prava nisu sredstvo zaštite ljudskih bića: ona stvaraju ljudska bića. Liberalno kreiranje subjektiviteta putem prava zasnovano je na „ograničenom poimanju 'ljudskosti'“, (Ibid) koje - ponovimo - predstavlja osobu kao biće lišeno 'posebnosti, kompleksnosti i materijalnosti'.

Radikalna ideja je jednostavna. Potrebni su nam emancipatorska ideja i praksa individualnih prava. Lako je pretvarati se da zakon harmonizuje i štiti, ako je predmet zaštite apstraktni racionalni identitet izmišljenih izolovanih 'monada'. Međutim, stvarni ljudi nikada nisu samo racionalna i izolovana bića. Mi smo situirani u društvo i često iracionalni; naši identiteti su konkretni. Osnovno je to da su naša neponovljiva svojstva relacione kategorije: interesi, emocije, strasti, naše (i)racionalno ponašanje i naši identiteti mogu se razumeti samo kao izvod društvenih odnosa u kojima živimo. U odgovoru, liberali mogu reći da im prihvatanje ovog empirijskog uvida ne predstavlja problem. Oni će takođe priznati da je taj uvid od ključnog značaja za vrednosno utemljenje i institucionalno uređenje zajednice. ${ }^{7}$ Međutim, liberalizam insistira da su apstraktna individualna 
 \\ POLITIČKE PERSPEKTIVE \\ ČLANCI I STUDIJE}

prava, vladavina prava (rule of law) i ograničena vlast neophodni kako bi se ljudska bića zaštitila od nepredvidivosti opisane kompleksnosti. Radikalni demokrati insistiraju na suprotnom stavu. Priznanje društvene kompleksnosti mora biti direktno prevedeno na jezik osnovnih prava:

Prava su institucionalni izraz borbe za međusobno priznanje; ona predstav-

ljaju važan doprinos stvaranju identiteta i izraženo su intersubjektivne, a ne individualističke prirode. (Douzinas 2000, 371)

Prava ne mogu odgovoriti na izazove društvenog pluralizma i sukoba tako što će se uzdići iznad društvenih procesa poput nekog konsenzusom uspostavljenog otelotvorenja zajedničkih vrednosti. Ustavne slobode ne dopiru do potlačenih radnika bangladeških fabrika u kojima vladaju nehumani uslovi rada, niti do zlostavljanih žena, ili diskriminisanih kulturnih, rasnih i etničkih manjina. Naprotiv, jezik liberalnih prava „znatno umanjuje mogućnost osmišljavanja, artikulacije i delanja na suprotstavljanju navedenim problemima, zlostavljanjima i nepravdama”. (Zigon 2014, 17) Društveno je konkretno; konkretno je lokalno, u geografskom i u identitetskom smislu.

Ovaj pristup mnoge teoretičare navodi na zaključak da nosioce prava treba odrediti na osnovu identiteta, pre svega na osnovu identiteta koji je nastao kao posledica pretrpljene patnje, diskriminacije i nepravde. Vendi Braun (Wendy Brown) nudi interesantnu analizu ovog pristupa. Ona polazi od kritike „atomističke ontologije, metafizike razdvajanja, odbrambenog etosa i apstraktne jednakosti” (Brown 1995, 6) liberalnih prava. Ali njena kritika nije jednostrana. Teorijske poteškoće, veli Braun, nastaju kada se prema pravima ophodimo kao prema pojmovima, čime se problem svodi na dogmatsku raspravu između suprotstavljenih škola mišljenja marksizma i liberalizma. Usmeravajući pažnju na radikalno-demokratski pristup pravima, Braun tvrdi da prigovori upućeni liberalizmu pogađaju i levičarski zahtev da se ugnjetavanim manjinama garantuju prava zasnovana na njihovom konkretnom identitetu. Takav 'pristup pravima kroz prizmu ranjivosti' (vulnerability approach) pogrešan je jer zahteva pravnu formalizaciju postojeće diskriminacije:

... Ako prava kodifikuju - čak i ako pri tom donekle ublažavaju - određene oblike podređenosti i izopštavanja, zadatak radikalnih demokrata nije naprosto da prošire spisak prava, već i da istraže istorijske i kulturne temelje na kojima bi ta prava bila zasnovana. (Ibid, 12)

U konačnom izvodu, tvrdi Braun, 'pristup pravima kroz prizmu ranjivosti' nije u stanju da ispuni Marksovo obećanje o ljudskoj emancipaciji. Marks nije 'promišljao pojmove'; on je proučavao istorijske uslove koji dovode do represivne vladavine. On je video prava kao otelotvorenje državne podrške ekonomskoj eksploataciji. Ali on je insistirao da mislimo s onu stranu države i ekonomije. To ujedno podrazumeva i prevazilaženje prava: slobodi i jednakosti lišenim determinizma eksploatacije prava više 
nisu potrebna. S druge strane, „najveći broj progresivnih mislilaca poznog dvadesetog veka odustao je od alternativnog poimanja slobode i jednakosti, prihvatajući viziju 'ekonomske pravde' koju garantuje i sprovodi država, i kombinujući takvu ekonomsku pravdu sa privatnim slobodama”. (Ibid, 1011) Radikalni demokrati, tvrdi Braun, zapravo žele više liberalnih sloboda. Njihovi zahtevi za zaštitom autonomije protežu se i na zaštitu individualnog statusa od socijalnih nepravdi. Takav zahtev za pravnim priznanjem 'istorijski proizvedene povrede' samo dalje jača državnu moć. Zato je taj zahtev konzervativan. Umesto toga, treba proučavati represivne procese nastanka političkog identiteta. (Chambers 2004, 188)

Ovaj poslednji stav čitalac će verovatno prepoznati kao locus classicus radikalno-demokratske kritike: ustavna prava odražavaju postojeće odnose moći. Ta kritika zbunjuje liberale: oni se slažu da liberalna prava štite ljudsko dostojanstvo od zloupotrebe moći. U čemu je onda problem? Prigovor glasi da liberali greše kad identifikuju državnu vlast kao glavnu pretnju slobodi. I ne samo to - oni pogrešno identifikuju i osnovnu vrednost koju treba štititi, jer ta vrednost nije lična autonomija. Društvena solidarnost, pravda i mogućnost slobodnog donošenja odluka o pitanjima od zajedničkog interesa istinske su vrednosti demokratije. Ako je politička zajednica doista naša ne moramo se plašiti njene moći.

Navedeni zaključak vraća nas na početak. Sukob liberala i radikalnih demokrata o pojmu i značaju osnovnih prava seže duboko: on se tiče statusa i sadržaja individualnih vrednosti, kolektivnog delanja i legitimnog načina njegovog regulisanja, granica državne vlasti, uloge zakona, sve do pitanja zašto smo zajedno.

\section{Pogled izNutra: \\ ŠTA SE DOGODILO SA AUTORITETOM LIBERALNIH PRAVA I ŠTA ČINITI?}

\subsection{DiJAgnOZA}

Kratka analiza ponuđena u prethodnom odeljku omogućava nekoliko opštih zaključaka. Prvo, kad je reč o ciljevima i korišćenim pojmovima vidimo značajno preklapanje između liberalnih i radikalno-demokratskih teorija. Međutim, to preklapanje pre svega je terminološke prirode: reči kao što su 'prava', 'pravda,' 'pluralizam,' 'politika,' 'zakon' ili 'demokratija' koriste se u dvema teorijama sa veoma različitim značenjima. Drugo, radikalna demokratska kritika 'apstraktne normativnosti' liberalnih prava ostaje zarobljena u teškom ideološkom vokabularu. Ona se prekomerno oslanja na različite varijante istrošenih marksističkih kritika kapitalizma. Štaviše, novija postmarksistička misao tu kritiku ponekad isuviše približava poziciji društvenog i političkog konzervativizma. Treće, ono što zastupnici libe- 
ralnih prava mogu naučiti, kako iz radikalno-demokratskih teorija tako i iz aktuelne krize liberalizma, potreba je za ponovnim definisanjem odnosa između individualizma, društvene i političke sfere. U preostalom delu rada pokušaću da odbranim ovu tezu. Polaziću od pretpostavke da liberalizam mora dokazati da doista ceni ljudsku slobodu i jednakost uobličene individualnim pravima. Oni koji svoja obećanja ne shvataju ozbiljno ne mogu očekivati od drugih da prihvate njihove reči i pretoče ih u delo.

Demokratija je u ozbiljnim teškoćama. ${ }^{8}$ To je moguće deskriptivno potkrepiti na više načina. Ukazaću na tri manifestacije krize. Pre svega, tu je razočaranje u demokratiju. Građani se dele na one koji su ravnodušni, one koji prihvataju populizam i one ogorčene koji se okreću različitim oblicima radikalnih protesta. Bez obzira kojoj grupi pripadaju, građani su u sve većoj meri ravnodušni prema pravima, odbacujući važnost liberalno shvaćene demokratije. Nazovimo to gubitkom političkog, moralnog i kulturnog autoriteta demokratije. Drugo, politička vlast, kako na domaćem tako i na međunarodnom planu, povlači se pred sve snažnijim privatnim akterima koji preuzimaju vladavinske poluge na netransparentan i nepredvidiv način. Nazovimo to globalizacijom: dominacija privatnih i kvazijavnih transnacionalnih aktera, njihovih preferenci, struktura koje su izgradili i procesa koje diktiraju. Praćena pomodnim teorijskim terminima kao što su 'upravljanje' (governance) i 'racionalnost politike' (policy rationality), globalizacija ne gleda blagonaklono na prava i ograničenje vlasti. Treće, demokratske države su možda izgubile mnogo od njihove sposobnosti političke vladavine, ali su zadržale sposobnost represije. Ta represija sve više ugrožava vladavinu prava, kao i sâma prava. Nazovimo to represivnom nesposobnošću vladanja (repressive ungovernability).

Ukratko, aktuelno stanje demokratije je sumorno; ne zna se šta se može očekivati u budućnosti. U institucionalnom smislu, još uvek možemo identifikovati pravno jednake građane, demokratsku vlast, političke organizacije, kao i zakone koji oblikuju politiku i društvo. Međutim, formalni kvalitet institucionalnog ustrojstva tone u isprazni formalizam. Čini se da je suštinski problem normativne prirode. Demokratije nisu u stanju da afirmišu sopstvene temeljne vrednosti: ličnu autonomiju, slobodu, jednakost, vladavinu prava, političko samoupravljanje građana, efikasnost i odgovornost vlasti.

Naravno, navedeni zaključak više je proizvod tumačenja nego objektivne dijagnoze. Svedočimo mnogim doktrinarnim sukobima, u političkoj nauci, političkoj i ustavnoj teoriji, sociologiji politike. Ne ulazeći u sadržinu ovih neslaganja, tvrdiću tek da nas ona podsećaju kako stanje demokratije nije samo analitičko i empirijsko, već je i normativno pitanje. Demo-

8 Ostatak rada delom se oslanja na moj tekst 'Democracy Disembedded' (Dimitrijević 2018). 
NENAD DIMITRIJEVIĆ

LIBERALNA PRAVA IZMEĐU RADIKALNE

DEMOKRATSKE KRITIKE I NEUSPEHA LIBERALIZMA

kratija nije samo institucionalni oblik režima, niti je samo politička praksa koja zadovoljava neke proceduralne kriterijume. Demokratija je i interpretativni koncept u čijem jezgru su neke vrednosti. Zato naši sporovi nikad nisu jednostavno sporovi o činjenicama. Mi se ne slažemo od koje tačke treba poći, šta je zaista važno, i na koji način je to važno. Ukratko, naš sud o stanju demokratije zavisi prvenstveno od toga kako razumemo ovaj koncept i praksu. Pre četvrt veka bili smo skloni da frazom o 'kraju istorije' izrazimo veru u konačnu pobedu ustavne demokratije nad totalitarnim i autoritarnim alternativama. Međutim, to se nije dogodilo. Budućnost je i dalje otvorena i nepredvidiva. Trenutno mračno stanje demokratije otkriva jednu novu dimenziju te otvorenosti. Danas mi kojima je stalo do demokratije možda trebamo da skupimo hrabrost i zapitamo se da li prisustvujemo kraju demokratije. Znam da će se ovo mnogima učiniti kao preterivanje. No može biti i da je danas „postalo moguće ono što je ranije bilo nemoguće i mora stoga biti i predmetom mišljenja”. (Luhmann 1992, 211).

Moja osnovna teza je jednostavna. Današnja situacija proizvod je dugotrajnog procesa u kome su liberalne demokratije zanemarivale vrednosti na kojima počivaju. To se može odrediti kao gubitak moralnog kodeksa koji bi definisao razliku između ispravnog i pogrešnog u našim individualnim životima i koji bi nam rekao šta našu zajednicu čini vrednom očuvanja (Wolfe 1989, 2). Kao posledica tog gubitka, kršenje prava postalo je stvar rutine, demokratske institucije su obesmišljene, razobučeno tržište proizvodi pogubne posledice, a globalizacija se pretvorila u stanje straha i nesigurnosti.

Živimo u stanju moralne, društvene i političke dezintegracije. Globalizacija je uspešno demontirala modernu demokratsku državu kakvu smo poznavali. Država više nije vrhovna vlast nad određenom teritorijom i ljudima koji žive unutar njenih granica. Pokidana je suštinska moderna veza između političke vlasti, demokratije kao političkog oblika vlasti i prava kao pretpostavljeno legitimnog sistema društvene koordinacije. Demokratska politika se povlači pred privatizovanim globalnim mehanizmima upravljanja koji egzistiraju i funkcionišu u vanustavnom prostoru. Moć je decentralizovana, umnožena, privatizovana i netransparentna. ${ }^{9}$ Politička vlast postepeno ustupa mesto upravljanju (governance), mutnom pojmu koji bi da objasni novu podelu moći između političkih i nepolitičkih aktera. Upravljanje, kao „vladavina preferenci i normi, režima i praksi čiji se centar ili etos ne mogu odrediti" (Koskenniemi 2011, 63), briše granice između domaćeg i globalnog, javnog i privatnog, političkog i ekonomskog. 
POLITIČKE PERSPEKTIVE

ČLANCI I STUDIJE

Ovo je praćeno urušavanjem vladavine prava. Sve do skorašnjih promena pretpostavljalo se da je društvena kompleksnost predmet pravne regulacije, te da pravo treba da bude efikasno, proceduralno legitimno i zasnovano na određenim supstantivnim vrednostima. Međutim, ovi zahtevi su danas gotovo potpuno odbačeni. Propadajuće domaće javno pravo i ograničeno međunarodno javno pravo suočavaju se sa pluralizmom pravnih režima koje za sebe stvaraju globalni akteri. Ovaj novi pravni pluralizam pati od nedostatka koordinacije (Teubner 1997, 7). Više se ne možemo služiti uobičajenim pravničkim kriterijumima - identifikacijom pravotvorca, procedurama stvaranja prava, ovlašćenjima koje pravo daje različitim telima - kako bismo uspostavili pravnu hijerarhiju. Norme koje proizvodi mnoštvo političkih i društvenih aktera tvore konglomerat, a ne pravni sistem (Somek 2014, 108-9). Pravo se svodi na puku zapovest, odnosno izraz volje onih koji poseduju društvenu moć. ${ }^{10}$

Primetićemo i da se globalni privatni akteri niti ne pretvaraju da im je stalo do političkog i pravnog legitimiteta. Državne vlasti ipak se ponašaju nešto drugačije. One moraju imati neku vrstu legitimiteta (Offe 20o6, 36). Pošto su lišene dobrog dela autoriteta koji im je garantovan ustavom, vlasti moraju dokazati da su i dalje bitne. Tu često možemo videti zanimljive kombinacije funkcionalnih i normativnih elemenata. Funkcionalno, državna vlast nameće podanicima različite policy constraints, poslušno izvršavajući naređenja istih onih spoljnih aktera koji podrivaju njen autoritet. Vladama je ostavljeno da svojim građanima predstave mere štednje, da sprovode tuđe politike i da guše mogući otpor tim politikama (Somek 2014, 108). One se često služe kompleksnim strategijama zasnovanim na ideološkoj manipulaciji zajedničkim vrednostima kako bi nadomestile nesposobnost da vladaju na osnovu ustavom propisanih pravila. Time se jaz između normativnog i funkcionalnog nekako premošćuje. Međutim, cena tog poduhvata je visoka: napušta se primat prava, liberalne neutralnosti i javne rasprave zarad preterano emotivnog, strasnog i iskrivljenog tumačenja navodnih zajedničkih vrednosti. To se zove populizam.

Konačno, vladajuća praksa današnjih demokratija poriče i ličnu i javnu autonomiju. Mi više nismo suvereni nosioci ličnih prava, niti se možemo smatrati građanima koji saodlučuju u poslovima zajednice. Naša prava više nikog ne obavezuju. Pravno desubjektivirani, politički obezvlašćeni i socijalno degradirani, bačeni smo u u prazan prostor: napušteni, ućutkani i zaboravljeni.

10 "Jezik zakona pretvara se u jezik transnacionalnih režima koji uvode najrazličitije smernice, direktive, de facto standarde i očekivanja”. (Koskenniemi 2006, 13) 
NENAD DIMITRIJEVIĆ

LIBERALNA PRAVA IZMEĐU RADIKALNE

DEMOKRATSKE KRITIKE I NEUSPEHA LIBERALIZMA

\subsection{KAKO MISLITI LIBERALNU TRANSFORMACIJU}

Kriza demokratija je duboka. Moć, shvaćena kao sposobnost upravljanja ljudima i događajima, sve je manje vezana za formalnu političku vlast. Vlastodršci su lišeni sposobnosti vladavine, a zauzvrat su oslobođeni odgovornosti. Građani su lišeni pretpostavljenog prava na ličnu i političku autonomiju. Stare izvesnosti više ne važe. Okrećem se izazovu mogućih promena priznajući da nemam jasnu predstavu o tome kako bi proces transformacije i alternativni institucionalni režim trebalo da izgledaju. Takođe priznajem postojanje psihološkog problema koju je lepo sročio Tomas Nejgl (Thomas Nagel): „Strah da ne izgovorimo glupost moćna je prepreka" (Nagel 1979, 2). Ipak, ne možemo suditi o značaju određenih pitanja na osnovu naše (ne)sposobnosti da odgovorimo na njih.

Teorija mora da se pozabavi kontekstom koji je znatno drugačiji od onoga u kom je moderna država nastala i razvila se u ustavnu demokratiju. Moramo se vratiti na početak i zapitati se zašto je institucionalni režim zasnovan na pravima moralno i politički atraktivan. Pred nama je ograničen broj mogućnosti. Ljudi posvećeni pravima mogu tragati za alternativnom verzijom demokratije, ili se zalagati za ponovno promišljanje liberalizma. Ne želeći da poreknem emancipatorsku vrednost i privlačnost mnogih praksi i teoretskih refleksija koje upućuju s onu stranu liberalne demokratije, smatram da one ipak pate od ozbiljnih nedostataka. Demokratski autoritet ne može se svesti na aranžman koji se približava ili praktično ispunjava ideal vladavine naroda ili mnoštva. Aktuelni talas populizma podseća nas na vrednost stare liberalne pouke: nema ničeg samog po sebi dobrog u neposredovanoj vladavini onih koje konvencionalne teorije identifikuju kao podanike. Prosta činjenica da smo mi narod ili mnoštvo ili podanici ne čini nas moralno superiornima. Mi smo kao podanici moralno superiorni samo ako je naša pozicija ispravna, a pozicija vlasti pogrešna.

Verujem da je liberalizam i dalje sposoban da osmisli svoje obećanje o garantovanju slobode i jednakosti. Međutim, on se mora suočiti sa sopstvenim demonima. Liberalizam vidim kao političku teoriju i institucionalni režim koji pokušava da objasni i reguliše suživot među ljudima koji sebe smatraju autonomnim osobama i koji prepoznaju da su svi ravnopravni subjekti ustavnih i ljudskih prava. Prava se liberalno mogu razumeti kao ovlašćenja koja oblikuju etički položaj svakog člana zajednice (šta je meni od lične koristi), moralnost odnosa između članova zajednice (kako ispravno tretirati druge) i vrednosne i institucionalne okvire zajedničkog života (pod kojim uslovima imamo političke obaveze). Ako su se demokratije danas udaljile od svojih vrednosnih osnova, moramo se iznova zapitati o značenju pojmova slobode i jednakosti. Stanje društvene i političke dezintegracije, opisano u odeljku 3.1, onemogućava mnogim ljudima slobodu koju propoveda liberalizam. Sve slabija liberalna prava, 
POLITIČKE PERSPEKTIVE

ČLANCI I STUDIJE

kako ona koja bi trebalo da važe na domaćem nivou tako i ona međunarodna, nisu od prevelike koristi onima koji ispaštaju zbog rastućih nejednakosti i gubitka građanskog statusa. Osnovni problem tiče se arbitrarne dominacije, pa je osnovni zadatak alternative da uspostavi režim oslobođen od arbitrarne zloupotrebe moći (Forst 2011, 5).

Polazna tačka alternative trebala bi biti normativna, a ne institucionalna. Fokus ne bi trebalo da bude na individualnoj slobodi već na ponovnom promišljanju značenja i dometa liberalne jednakosti. Identifikovanje jednakosti kao centralne tačke zajedništva nije ekskluzivno socijalistička teza. Međutim, svaki pokušaj da se redefiniše liberalna jednakost suočava se sa najmanje tri poteškoće. Prvi problem tiče se odnosa jednakosti i slobode. Drugi problem je motivacija za jednakost. Treći problem je institucionalizacija jednakosti. Pažnju ću posvetiti problemu motivacije, koji je delimično psihološke naravi. Na prvi pogled nije jasno zašto bi određena osoba samoinicijativno pristala da prilagodi svoje ponašenje, ciljeve i delovanje zahtevima jednakosti. Klasična liberalna postavka o primatu usko shvaćenog ličnog interesa deluje daleko realnije: ako je moja autonomija najpre izražena kao princip slobode i oblikovana ustavnim pravima koja mi dozvoljavaju da nastavim sa svojim delovanjem slobodan od mešanja drugih, pitanje jednakosti javlja se kao posledica racionalne računice koja zahteva uspostavljanje ravnoteže između zaštite privatne sfere i političke stabilnosti. Međutim, treba ponoviti da je ta računica prevaziđena. Privatizacija ličnog interesa $u$ današnje vreme u velikoj meri nije ograničena zakonom, što urušava kako lična prava tako i ustavnu demokratiju. Reformistički projekat usmeren ka ponovnom uspostavljanju autoriteta ljudskih prava trebalo bi da u obzir uzme sledeće tačke: prvo, svaka osoba mora biti zaštićena od socijalnih i političkih rizika nad kojima nema kontrolu; drugo, socijalni i politički status ne sme biti kriterijum na osnovu koga bismo jednu osobu smatrali manje ili više vrednom; treće, institucionalno uređenje demokratije mora garantovati da nijedna osoba neće biti diskriminisana zbog razloga na koje ne može uticati.

Sledi da stvaranje uslova za jednakost nije samo stvar redistributivne pravde. Glavni zadatak bio bi dokidanje arbitrarne vladavine uspostavljanjem stanja u kojem bi svi nosioci moći - politički, ekonomski i društveni - posedovali legitimitet. To bi zahtevalo promenu položaja privatnih i netransparentnih ekonomskih i finansijskih moćnika, koji danas uživaju arbitrarnu - ne-pravnu i ne-političku - moć. Oni bi se morali izvesti iz privatnog domena i pravno definisati kao javne organizacije, kako bi se podvrgli zahtevu vladavine prava. Njihov položaj, nadležnosti i delovanje trebalo bi regulisati domaćim ustavnim i međunarodnim javnim pravom. Ukratko, ekonomske i finansijske aktere treba ukloniti iz životnog prostora koji su kolonizovali, a zatim ih postaviti u javne okvire novih demokratskih 


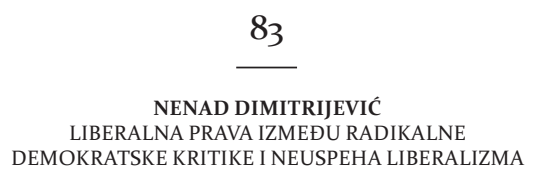

sistema, kako nacionalnih tako i globalnih. Taj poduhvat bi takođe podrazumevao i duboku reformu formalnih političkih vlasti. One bi morale biti mnogo jasnije postavljene, što bi podrazumevalo mnogo precizniju podelu nadležnosti, odnosno uspostavljanje skupa nedvosmislenih, apstraktnih i delotvornih pravila koja bi odredila šta vlast sme a šta ne sme da radi. Obnova konstitucionalizma kao normativnog projekta zahtevala bi opštu obaveznost, transparentnost i predvidljivost hijerarhijski uređenog svetskog pravnog režima. Ta obnova podrazumevala bi poštovanje autonomije pojedinaca, država i svih kolektivnih društvenih aktera koji poštuju pravo na globalnom nivou, a takođe bi podrazumevala i rekonstrukciju međunarodnog javnog prava. Rekonstrukcija međunarodnog javnog prava trebala bi ići u smeru konstitucionalizacije, što bi uključivalo jasno definisanje autoriteta ljudskih prava, demokratski legitimnih međunarodnih političkih institucija, kao i uspostavljanje novog međunarodnog sudskog sistema. Cilj bi bio reafirmacija „velike trijade” ustavne demokratije, koja zahteva posvećenost jednakim univerzalnim pravima, vladavini prava i demokratiji. (M. Kumm et al. 2014, 3)

Preveo s engleskog: Jovica Pavlović

\section{LITERATURA}

Badiou, Alain. 2012. The Rebirth of History. Times of Riots and Uprisings. London: Verso.

Badiou, Alan. 2013. Ethics. An Essay on the Understanding of Evil. London: Verso.

Bailey, Saki and Mattei, Ugo. 2013. "Social Movements as Constituent Power: The Italian Struggle for the Commons". Indiana Journal of Global Legal Studies, 20(2): 965-1013. doi: 10.2979/indjglolegstu.20.2.965

Brown, Wendy. 1995. States of Injury. Power and Freedom in Late Modernity. Princeton: Princeton University Press.

Chambers, Samuel. 2004. 'Giving Up (on) Rights? The Future of Rights and the Project of Radical Democracy'. American Journal of Political Science, 48(2): 185-200.

Colebrook, Claire. 2015. 'Resistance to Occupy'. In Ed. A. Conio, Occupy. A People yet to Come. London: Open Humanities Press. 125-157. http://openhumanitiespress.org/books/download/Conio_2015_Occupy-A-People-Yet-To-Come.pdf (accessed 23. 10. 2019).

Cox, Christoph, Whalen Molly, and Alain Badiou 2001. 'On Evil: An Interview with Alain Badiou', 5 Cabinet. (2001-2002). http://www.cabinetmagazine.org/issues/5/alainbadiou.php (accessed 23. 10. 2019). 


\section{4 \\ POLITIČKE PERSPEKTIVE \\ ČLANCI I STUDIJE}

Dimitrijević, Nenad. 2016. 'Constitutional Theory in Times of Crisis: Power, Law and Morality'. Philosophy and Social Criticism, 42(3): 227-245. doi: doi.org/10 .1177/0191453715598552

Dimitrijević, Nenad. 2018. 'Democracy Disembedded'. Philosophy and Social Criticism, 44(10): 1049-1070. doi: 10.1177/0191453718779178

Douzinas, Costas. 200o. The End of Human Rights. Critical Legal Thought at the Turn of the Century. Oxford: Hart Publishing.

Forst, Rainer. 2011. 'Transnational Justice and Democracy', Normative Orders Working Paper. 4. https://pdfs.semanticscholar.org/c6a8/8oed59bd6c53bi5e7f9437bfdd362504aofa.pdf (accessed 23. 10. 2019).

Grear, Anna. 2007. 'Challenging Corporate Humanity: Legal Disembodiment, Embodiment, and Human Rights'. Human Rights Law Review, 7(3): 511-543 doi:10.1093/hrlr/ngmo13

Hardt, Michael and Negri, Antonio. 2012. Declaration, 13. 2012. https://antonionegriinenglish.files.wordpress.com/ 2012/05/93152857-hardt-negri-declaration-2012.pdf (accessed 23. 10. 2019)

Ingram, James. 2006. 'The Politics of Claude Lefort's Political: Between Liberalism and Radical Democracy'. Thesis Eleven, 87(1): 33-50. doi: 10.1177/07255136 o6068774.

Kennedy, David W. 2012. 'The International Human Rights Regime: Still Part of the Problem?' In Eds. R. Dickinson et al., Examining the Critical Perspective on Human Rights. Cambridge, UK: Cambridge University Press. 19-34.

Kennedy, Duncan. 2002. 'The Critique of Rights in Critical Legal Studies'. In Eds. W. Brown and J. Haley. Left Legalism - Left Critique. Durham: Duke University Press. 178-228.

Koskenniemi, Martti. 2006. 'Constitutionalism as a Mindset. Reflections on Kantian Themes About International Law and Globalization'. Theoretical Inquiries in Law, 8(1): 9-36. 13. doi: 10.2202/1565-3404.1141

Koskenniemi, Martti. 2011. 'What Use for Sovereignty Today?' Asian Journal of International Law, 1(1): 61-70. doi:10.1017/S2044251310000044

Kumm, Mattias, Lang, Anthony F. Tully, James and Wiener, Antje. 2014. "How Large Is the World of Global Constitutionalism?" Global Constitutionalism, 3(1): 1-8. doi: 10.1017/S204538171400001X.

Lenin, Vladimir Ilyich. 1962. 'Two Tactics of Social-Democracy in the Democratic Revolution”. Collected Works, Vol. 9. Moscow. https://www.marxists.org/archive/lenin/works/1905/tactics/index.htm (accessed 23. 10. 2019).

Lenin, Vladimir Ilyich. 1977. 'Left-Wing Communism: An Infantile Disorder'. Collected Works, Vol. 31. Moscow. https://www.marxists.org/archive/lenin/works/1920/lwc/index.htm (accessed 23. 10. 2019).

Luhmann, Niklas. 1992. Legitimacija kroz proceduru. Zagreb: Naprijed. 


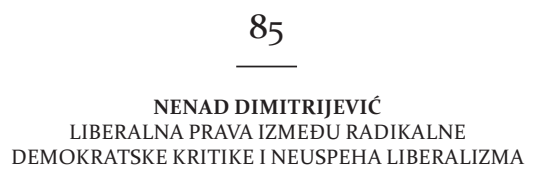

Marx, Karl. 1989. 'Prilog jevrejskom pitanju'. U K. Marx i F. Engels. Rani radovi. Zagreb: Naprijed.

Mattei, Ugo. 2011. 'The State, the Market, and some Preliminary Questions about the Commons'. http://works.bepress.com/ugo_mattei/4o/

Mattei, Ugo. 2013.'Protecting the Commons: Water, Culture, and Nature. The Commons Movement in the Italian Struggle against Neoliberal Governance'. The South Atlantic Quarterly, 112 (2): 366-376. doi: 10.1215/00382876-2020244368.

McNeilly, Kathryn. 2016. 'After the Critique of Rights: For a Radical Democratic Theory and Practice of Human Rights'. Law Critique, 27 (3): 269-288. doi: 10.1007/s10978-016-9189-9

Mouffe, Chantal. 1992. 'Democratic Politics Today'. In Ed. Ch. Mouffe. Dimensions of Radical Democracy. London: Verso.

Mouffe, Chantal. 1993. The Return of the Political, London: Verso.

Nagel, Thomas. 1979/2013. Mortal Questions. Cambridge: Cambridge University Press. doi:10.1017/CBO9781107341050

Offe, Claus. 2006. 'Political Disaffection as an Outcome of Institutional Practices? Some Post-Tocquevillean Speculations'. In Eds. M. Torcal and J. R. Montero. Political Disaffection in Contemporary Democracies. Social Capital, Institutions, and Politics, 23-45. London: Routledge.

Ranciere, Jacques. 2005. Hatred of Democracy, London: Verso.

Sajó, András and Uitz, Renáta. 2017. The Constitution of Freedom: An Introduction to Legal Constitutionalism. Oxford: Oxford University Press. doi:10.1093/o so/9780198732174.001.00o1

Sciaraffa, Stefan. 1999. “Critical Legal Studies: A Marxist Rejoinder”. Legal Theory, 5(2): 201-19. doi: 10.1017/S1352325299052040.

Somek, Alexander. 2014. The Cosmopolitan Constitution. Oxford: Oxford University Press.

Teubner, Gunther. 1997. 'Global Bukowina: Legal Pluralism in the World Society'. In Ed. G. Teubner. Global Law Without a State, Dartmouth: Aldershot. 3-28.

Wolfe, Alan. 1989. Whose Keeper? Social Science and Moral Obligation. Berkeley: University of California Press.

Zigon, Jarrettt. 2014. 'Maintaining the Truth: Performativity, Human Rights, and the Limitations of Politics'. Theory and Event, 17(3). https://www.muse.jhu. edu/article/553385. 
POLITIČKE PERSPEKTIVE

ČLANCI I STUDIJE

\section{SUMMARY \\ Liberal Rights Between Radical Democratic CritiQue AND LIBERAL FAILURE}

This article departs from the claim that the fading respect for rights is the most troublesome feature of the current condition of liberal democracy. A background assumption is that democracy is not a value in itself. Constitutional democracy is a legitimate political arrangement only if it effectively upholds and protects personal autonomy of its citizens. The focus of the text is on the radical democratic critique of liberal rights, but it does not aim at offering a comprehensive overview of diverse radical democratic theories. It is organized around the points of contestation between radical democratic and liberal constitutionalist readings of rights. The second section of the article summarizes the concept of radical democracy and introduces a provisional classification of radical democratic approaches to rights. It distinguishes between two groups of theories: those that reject rights and those that call for a reconceptualization of rights along non-liberal lines. The analysis focuses on the points of contestation with liberal rights. Section three argues for the need to revisit the standard liberal reading of the relative separation between personal, social and political realms. The author's main normative claim is that the crisis of liberal rights is an outcome of a long process in which liberal democracies gradually abandoned their normative foundations. When considering possible paths of rehabilitation of the legal and moral authority of liberal rights, thinking beyond the given is not the worst option. The core question is how to think of, and how to practically affirm, personal autonomy in the present context.

KEYwORDs: liberal rights, radical democratic critique, liberalism, constitutional democracy. 